\title{
SURVEI MANAJEMEN PEMBINAAN PRESTASI CABANG OLAHRAGA BULUTANGKIS DI PB GANESHA KOTA BATU
}

\author{
Adi Pratama \\ Ilmu Keolahragaan \\ Universitas Negeri Malang \\ Jl. Semarang 5 Malang, 65145,Indonesia \\ adi_pratama9b@yahoo.co.id \\ Supriyadi \\ Ilmu Keolahragaan \\ Universitas Negeri Malang \\ Jl. Semarang 5 Malang, 65145,Indonesia \\ Slamet Raharjo \\ Ilmu Keolahragaan \\ Universitas Negeri Malang \\ Jl. Semarang 5 Malang, 65145,Indonesia
}

\begin{abstract}
ABSTRAK
Penelitian ini bertujuan untuk menganalisis manajemen pembinaan prestasi cabang olahraga bulutangkis di PB Ganesha Kota Batu. Penelitian ini menggunakan metode penelitian kuantitatif dengan cara survei menggunakan angket dan menghasilkan data deskriptif kuantitatif. Berdasarkan hasil penelitian menunjukkan bahwa: (1) Manajemen Pembinaan Prestasi Bulutangkis di Kota Batu dengan kategori "baik sebesar 0\%". Kategori "cukup" sebesar 32\%, kategori "kurang baik" sebesar 68\%, kategori "tidak baik" sebesar $0,(2)$ faktor internal berada pada kategori "baik" sebesar $0 \%$, kategori "cukup" sebesar $32 \%$, kategori "kurang baik" sebesar 68\%, kategori "tidak baik" sebesar $0 \%$, (3) faktor eksternal berada pada kategori "baik" sebesar 0\%, kategori "cukup" sebesar 36\%, kategori "kurang baik" sebesar 64\%, kategori "tidak baik" sebesar 0\%. Berdasarkan hasil penelitian disimpulkan bahwa manajemen pembinaan prestasi cabang olahraga bulutangkis di PB Ganesha Kota Batu memiliki manajemen pembinaan kurang baik.
\end{abstract}

Kata kunci: bulutangkis, manajemen, pembinaan prestasi olahraga

Olahraga merupakan suatu kegiatan jasmani yang bertujuan untuk prestasi, rekreasi, pendidikan dan meningkatkan kualitas kesehatan (Giriwijoyo dan Sidik, 2012:18). Menurut (Tohidin, 2007:2) menjelaskan bahwa olahraga merupakan suatu kegiatan jasmani yang bertujuan untuk memperkuat dan meningkatkan kemampuan otot, meningkatkan kebugaran jasmani, meningkatkan kualitas kesehatan dan meningkatkan keterampilan gerak dasar. Olahraga memiliki berbagai manfaat bagi kesehatan tubuh, seperti mempertahankan dan memelihara kemampuan gerak, meningkatkan kekuatan dan daya tahan otot, meningkatkan kapasitas aerobik (Giriwijoyo dan Sidik, 2012:18). Selain dapat menyehatkan tubuh, olahraga juga dapat menurunkan kualitas kesehatan dan kinerja fisik jika dilakukan dengan dosis yang berlebihan (Sugiharto, 2014:31). Olahraga harus dilakukan dengan aman, nyaman dan menyenangkan serta sesuai dengan kemampuan dari masingmasing individu, agar dapat meningkatkan kapasitas fungsional tubuh, sehingga dapat meningkatkan kualitas kesehatan (Simanjuntak et al., 2016:21; Sugiharto, 2014:31).

Olahraga bulutangkis adalah salah satu olahraga yang digemari di kalangan masyarakat. Olahraga bulutangkis merupakan salah satu olahraga terpopuler di Indonesia dari dahulu hingga sekarang. Bagi bangsa Indonesia olahraga bulutangkis merupakan olahraga untuk semua lapisan masyarakat, karena dapat dimainkan oleh anak-anak, dewasa, laki- 
laki dan perempuan baik untuk tujuan rekreasi dan hiburan, menjaga kualitas kesehatan dan kebugaran maupun untuk meraih prestasi (Putra dan Sugiyanto, 2016:176). Dalam cabang olahraga khususnya bulutangkis untuk meraih prestasi pelatih tidak boleh menerapkan pendekatan tidak ilmiah atau tidak sesuai dengan prinsip-prinsip dasar latihan, yaitu menerapkan begitu saja program latihan atlet-atlet top kepada atlet-atlet binaan dan mengabaikan kekhasan karakteristik atlet, kemampuan dan pengalaman di masa lalu (Harsono, 2015:67). Pembinaan atlet perlu direncanakan dan disesuaikan bagi setiap individu agar dengan demikian latihan tersebut dapat menghasilkan hasil yang terbaik (Harsono, 2015:66). Dalam usaha pencapaian prestasi pelatih harus merencanakan program pelatihan yang baik, mengorganisasi-kan keperluan terkait pencapaian prestasi tersebut perlu didampingi dengan pelatih yang memiliki kualifikasi dan kompetensi pelatih yang profesional, pelatih mengawasi dan mengontrol program pelatihan dan terakhir adalah mengevaluasi hasil dari prestasi yang kita raih (Sule dan Saefullah, 2005:1). Selain perencanaan pembinaan yang baik, untuk mencapai prestasi membutuh-kan kesadaran, kedisiplinan, ke-sabaran dan keuletan atlet bulu tangkis untuk meningkatkan ke-mampuan atlet. Prestasi tidak dapat dicapai dalam hitungan minggu atau bulan, melainkan dalam hitungan tahun karena atlet harus meningkat-kan kemampuan fisiologis tubuhnya. Kemampuan fisiologis tubuh dapat ditingkatkan dengan latihan yang teratur, terukur, berkesinambungan dan menyenangkan serta dalam jangka waktu yang lama agar kemampuan tubuh dapat meningkat secara optimal. Selain itu, juga dibutuhkan manajemen yang baik dalam klub karena dengan manajemen yang terencana dengan baik sebuah klub akan memiliki peluang untuk meraih prestasi sesuai yang diharapkan.

Di sisi lain, tidak semua klub bulutangkis memiliki manajemen pembinaan dan pengorganisasian yang sesuai dengan standard menejemen pada umumnya, salah satunya adalah klub bulutangkis PB Ganesha Kota Batu yang belum memiliki program manajemen sesuai standart. Standart yang seharusnya pada prinsipnya manajemen memiliki unsurunsur planning, organizing, leading or actuating (kepemimpinan) dan controlling (Sule dan Saefullah, 2005:25). Prestasi yang diraih atlet Kota Batu cenderung stagnan dan kurang bersaing di tingkat regional maupun nasional. Berkembang atau tidaknya olahraga bulutangkis tergantung bagaimana penerapan manajemen organisasi untuk pembinaan di suatu klub. Pusat pelatihan bulutangkis di PB Ganesha Kota Batu sudah lama berdiri namun belum ada atlet yang dapat meraih prestasi di level nasional maupun internasional, bahkan PB Ganesha Kota Batu kesulitan bersaing di kawasan regional pada cabang olahraga bulutangkis. Dengan mengetahui keadaan dan permasalah-an pada klub PB Ganesha Kota Batu, yakni mengenai kurang berkembang dan peningkatan prestasi maka perlu diadakanya penelitian survei lebih lanjut tentang manajemen pembinaan olahraga prestasi pada klub PB Ganesha Kota Batu.

Atas dasar latar belakang di atas maka peneliti ingin melaksana-kan penelitian dengan judul survei manajemen pembinaan prestasi pada cabang olahraga bulutangkis di PB Ganesha Kota Batu. Diharapkan hasil penelitian ini dapat digunakan sebagai dasar evaluasi untuk meningkatkan kualitas manajemen di PB Ganesha Kota Batu agar PB Ganesha Kota Batu dapat menciptakan atlet yang berkualitas dan memiliki karakter "good attitude" dan "sportpersonship" di masa depan.

\section{METODE}

Penelitian ini merupakan penelitian deskriptif kuantitatif dengan metode survei. bentuk survei yang dilakukan salah satunya mengenai job analysis yang bertujuan untuk mengumpulkan informasi mengenai tugas- 
tugas umum dan tanggung jawab para karyawan, aktivitas khusus yang dibutuhkan, keterlibatan dan fungsi anggota organisasi serta kondisi kerja dan fasilitas. Populasi yang digunakan dalam penelitian ini seluruh komponen klub PB Ganesha Kota Batu yang terdiri dari jajaran manajemen pengurus, pelatih dan atlet, sedangkan sampel pada penelitian ini adalah seluruh komponen klub PB Ganesha Kota Batu berjumlah 25 orang yang terdiri dari jajaran manajemen 2 orang, pelatih 4 orang dan atlet 19 orang.

Penelitian dilaksanakan di Gor Ganesha yang bertempat di Jl. Kartini Kelurahan Sisir Kecamatan Batu Kota Batu, sedangkan waktu pelaksaan penelitian pada Bulan November 2018 Februari 2019. Instrumen penelitian yang digunakan dalam penelitian ini adalah Tabel 1 Hasil Analisis Statistika Deskripsi Survei Manajemen Pembinaan Prestasi Bulutangkis Sudut Pandang Pengurus, Pelatih dan Atlet di PB Ganesha Kota Batu dengan angket, observasi dan wawancara. Teknik analisis data yang digunakan dalam penelitian ini adalah menggunakan uji deskriptif dengan rumus sebagai berikut.

$\mathrm{P}=\frac{F}{N} \times 100 \%$

Keterangan:

$\mathrm{P} \quad$ : Angka presentase

$\mathrm{F} \quad$ : Frekuensi

N : Jumlah Responden

\section{HASIL}

Berdasarkan hasil survei manajemen pembinaan prestasi bulutangkis di Kota Batu menunjukkan bahwa skor terendah (minimum) 99, skor tertinggi (maksimum) 236, rerata (mean) 168.52, standar deviasi (SD) 40.636. Untuk lebih jelasnya dapat dilihat pada tabel 1 sebagai berikut.

\begin{tabular}{lccccc}
\hline \multicolumn{6}{c}{ Descriptive Statistics } \\
\hline Responden & N & Minimum & Maximum & Mean & Std. Deviation \\
\hline
\end{tabular}

Tabel 2 Distribusi Frekuensi Survei Manajemen Pembinaan Prestasi Bulutangkis Sudut Pandang Pengurus, Pelatih dan Atlet

\begin{tabular}{lccc}
\hline \multicolumn{1}{c}{ Kualifikasi } & Interval nilai & Frekuensi & Persentase \\
\hline Baik & $271-360$ & 0 & $0 \%$ \\
Cukup & $181-270$ & 8 & $32 \%$ \\
Kurang baik & $91-180$ & 17 & $68 \%$ \\
Tidak baik & $1-90$ & 0 & $0 \%$ \\
\hline
\end{tabular}

\section{Faktor Internal}

Berdasarkan hasil survei manajemen pembinaan prestasi bulutangkis di PB Ganesha Kota Batu. Berdasarkan faktor internal diperoleh skor terendah

Tabel 3 Hasil Analisis Statistika Descriptive Faktor Internal (minimum) 29, skor tertinggi (maksimum) 74, rerata (mean) 50.24, standar deviasi (SD) 12.511. Untuk lebih jelasnya lihat tabel 3 sebagai berikut.

\begin{tabular}{lccccc}
\hline \multicolumn{5}{c}{ Descriptive Statistics } \\
\hline Faktor Internal & N & Minimum & Maximum & Mean & Std. Deviation \\
\hline
\end{tabular}


Tabel 4 Distribusi Frekuensi Survei Manajemen Pembinaan Prestasi Bulutangkis di PB Ganesha Kota Batu Berdasarkan Faktor Internal

\begin{tabular}{lccc}
\hline \multicolumn{1}{c}{ Kualifikasi } & Interval Nilai & Frekuensi & Persentase \\
\hline Baik & $82-108$ & 0 & $0 \%$ \\
Cukup & $55-81$ & 8 & $32 \%$ \\
Kurang baik & $28-54$ & 17 & $68 \%$ \\
Tidak baik & $1-27$ & 0 & $0 \%$ \\
\hline
\end{tabular}

Faktor Eksternal

Berdasarkan hasil survei manajemen pembinaan prestasi bulutangkis di PB Ganesha Kota Batu berdasarkan faktor eksternal diperoleh skor terendah

Tabel 5 Hasil Analisis Statistika Descriptive Faktor Eksternal

\begin{tabular}{lccccc}
\hline \multicolumn{6}{c}{ Descriptive Statistics } \\
\hline Faktor Eksternal & 25 & 70 & 167 & 118.28 & 28.826 \\
\hline
\end{tabular}

Tabel 6 Distribusi Frekuensi Survei Manajemen Pembinaan Prestasi Bulutangkis di PB Ganesha Kota Batu berdasarkan Faktor Eksternal

\begin{tabular}{lccc}
\hline \multicolumn{1}{c}{ Kualifikasi } & Interval Nilai & Frekuensi & Persentase \\
\hline Baik & $190-252$ & 0 & $0 \%$ \\
Cukup & $127-189$ & 9 & $36 \%$ \\
Kurang baik & $64-126$ & 16 & $64 \%$ \\
Tidak baik & $1-63$ & 0 & $0 \%$ \\
\hline
\end{tabular}

\section{PEMBAHASAN}

Berdasarkan hasil survei menunjukkan bahwa manajemen pembinaan prestasi bulutangkis di PB Ganesha masuk kategori "Kurang Baik". Hal ini disebabkan karena dua faktor yang mempengaruhi yaitu faktor internal dan faktor eksternal.

\section{Faktor Internal}

Faktor internal atau faktor yang berasal dari dalam adalah faktor pendukung yang sangat penting dalam proses pembinaan prestasi khususnya bulutangkis. Kondisi fisik merupakan salah satu syarat yang dibutuhkan dalam setiap usaha peningkatan prestasi atlet, bahkan dapat dijadikan sebuah landasan titik tolak suatu awalan prestasi (Oktian, 2016:239). (minimum) 70, skor tertinggi (maksimum) 167 , rerata (mean) 118.28 , standar deviasi (SD) 28.826. Untuk lebih jelasnya lihat tabel 5 sebagai berikut. 
Mental, (4) Kematangan Juara (Sajoto, 1995:7). Kemudian faktor-faktor penentu pencapaian olahraga antara lain, aspek biologis terdiri dari: (1) Potensi atau kemampuan dasar tubuh yang meliputi kekuatan, kecepatan, kelincahan, tenaga, daya tahan otot, daya kerja jantung dan paru-paru, kelentukan, keseimbangan, ketepatan dan kesehatan untuk olahraga, (2) fungsi organ-organ tubuh yang meliputi: daya kerja jantung, peredaran darah, daya kerja paru-paru, daya kerja pernapasan, daya kerja panca indra, (3) struktur dan postur tubuh yang meliputi ukuran tinggi dan panjang tubuh, ukuran besar, lebar dan berat tubuh, (4) gizi yang meliputi jumlah makanan yang cukup, nilai makanan yang memenuhi kebutuhan, variasi makanan (Sajoto, 1995:1).

Kebugaran jasmani yang baik didapatkan dari latihan fisik yang teratur dan baik. Dalam cabang olahraga, latihan merupakan hal utama yang paling memberi dampak secara langsung terhadap penampilan atau prestasi sebuah cabang olahraga (Baker dan Sean, 2004:212). Menurut Kusnaedi et al. (2016:23) secara umum, pengembangan lebih dulu atlet harus berfokus utama pada pengembangan multilateral, yang menargetkan pengembangan keseluruhan kemampuan fisik dari atlet. Aprilia et al. (2018:57) Dalam pembuatan program latihan yang diutamakan adalah bagaimana terjadinya asas overcompensation atau efek latihan pada tubuh yaitu semua yang terjadi dalam latihan. Bagaimanapun, jika pembebanan latihan terlalu ringan, efek latihan setelah pemulihan akan menjadi kurang dari yang diharapkan. Jika pembebanan latihan terlalu besar/berat maka kondisi akan kembali seperti semula. Dari pembebanan yang terjadi maka jika latihan terlalu ringan tingkat kelelahannya rendah/ sedikit, waktu pemulihannya singkat, dan efek latihannya (stimulus baru) sedikit dan terlalu awal. Apabila latihan terlalu berat maka tingkat kelelahan tinggi/banyak membutuhkan pemulihan yang lama, sehingga efek latihannya rendah dan stimulus baru menjadi terlambat. Untuk dapat memperoleh asas over compensation maka setiap latihan harus menurut dengan prinsip-prinsip latihan. Adapun prinsipprinsip dasar program latihan menurut Bompa dan Haff (1994:131) adalah: 1) Individual Needs (kebutuhan individu), 2) Kekhususan (specialization), 3) Progressive, 4) Overload (beban lebih), 5) Recovery (pemulihan), dan 6) Reversibility (kebalikan).

Semakin berkembangnya atlet, proporsi dari pelatihan khususnya, yang lebih berfokus kepada kemampuan yang diinginkan dalam olahraga tertentu, turut mengikat. Prestasi puncak atlet "Golden Age" adalah sekitar umur 20 tahun, oleh karena itu pembinaan atlet untuk mencapai prestasi puncak membutuhkan waktu kurang lebih 10 tahun. Berkenaan dengan itu PBSI dalam pembinaannya mengelompok-kan umur siswa/atlet menjadi kelompok-kelompok sebagai berikut:

1. Kelompok Pemula, berumur di bawah 11 tahun.

2. Kelompok Remaja A, berumur di bawah 13 tahun.

3. Kelompok Remaja B, berumur dibawah 15 tahun.

4. Kelompok Taruna, berumur di bawah 18 tahun.

5. Kelompok Dewasa, berumur di atas 18 tahun.

Olahraga merupakan aktivitas fisik yang memerlukan keterampilan dan juga energi yang cukup besar untuk melakukannya (Azizin, 2014:18). Perkembangan fisik atlet perlu diperatikan melalui asupan-asupan gizi yang tercukupi atlet diharapkan lebih cepat berkembang. Salah satu faktor imbulnya cedera dalam olahraga bulutangkis yaitu nutrisi yang kurang seimbang, lebih kecil kemungkinan mendapatkan cedera bila seseorang atlet memiliki keseimbangan nutrisi yang baik dan penyembuhan akan lebih cepat karena nutrisi yang dibutuhkan tubuh untuk recovery terpenuhi dengan baik (Novita, 2010:25) asupan zat gizi merupakan salah 
satu faktor penentu pada kebugaran. Asupan gizi yang baik akan menghasilkan energi yang cukup pula, karena energi dibutuhkan oleh tubuh untuk melakukan aktivitas sehari-hari (Putri, 2015:43). Kebugaran jasmani adalah suatu kemampuan tubuh yang berfungsi secara efisien dan efektif (Corbin et al., 2019:23). Kebugaran jasmani dipengaruhi oleh berbagai macam faktor, diantaranya sistem respirasi, kadar hemoglobin, sistem otot, sistem metabolisme, dan status gizi, serta tergantung pada umur, jenis kelamin, program aktivitas jasmani, dan latihan olahraga (Sarwono, 2008:47). Selain itu, terdapat makanan dan minuman yang dikonsumsi akan meningkatkan performa selama aktivitas fisik seperti konsumsi vitamin, mineral ataupun berupa suplementasi (Magfirah et al., 2013:1).

Penerapan manajemen pembinaan prestasi yang diterapkan di PB Ganesha belum maksimal, dengan terbukti prestasi yang di peroleh PB Ganesha Kota Batu masih kalah dengan Kota/Kabupaten yang lainnya, ini dikarenakan kurangnya perhatian dari pemerintah melalui programprogram untuk kemajuan pelatihan, kurangnya jam terbang bagi para atlet-atlet yang minimnya mengikuti pertandinganpertandingan bulutangkis yang diadakan. Salah satu cara yang efektif untuk melihat kualitas bertanding atlet meningkat atau tidak, yaitu dengan cara memberikan kesempatan kepada para atlet untuk sering mengikuti pertandingan sebagai jam terbang atlet, semakin banyak jam terbang maka peluang berprestasi semakin tinggi.

Atlet atau anak didik adalah komponen terpenting dalam suatu proses pembinaan, untuk itu perlunya pembinaan yang tepat yang diberikan kepada atlet. Dengan pembinaan yang tepat, diharapkan atlet dapat mengembangkan kemampuan dan juga potensi yang mereka miliki secara maksimal kemudian atlet dapat mencapai prestasi secara optimal, serta meningkatkan prestasi olahraga khususnya bulutangkis di PB Ganesha Kota Batu. Bulutangkis di PB Ganesha Kota Batu melakukan pembinaan atlet usia dini sampai remaja. Pada pembinaan atlet di PB Ganesha Kota Batu jarang sekali melakukan pemilihan, pemilihan atlet hanya pada saat akan dilakukan pertandingan saja dan setelah terpilih tidak ada pembinaan yang intensif tetapi atlet yang terpilih untuk pertandingan diberikan kepada pelatih masing-masing untuk dilatih dan di siapkan ke pertandingan yang akan diikuti, semua itu dilakukan karena terbatas oleh dana.

Menurut Suharno (1993:2) unsurunsur yang perlu mendapat pembinaan dari seorang atlet agar dapat mencapai prestasi yang optimal adalah pembinaan fisik, pembinaan teknik, pembinaan taktik, mental, kematangan bertanding dan pembangunan keterampilan. Dengan demikian, keberhasilan dalam suatu proses pembinaan bulutangkis harus diperhatikan pembinaan dari dalam atlet tersebut, karena dalam proses latihan tujuannya untuk mengembangkan potensi, bakat dan minat yang dimiliki oleh atlet. Oleh karena itu, faktor pendukung untuk mendapatkan pembinaan yang memuaskan secara maksimal harus didukung oleh motivasi dari atlet itu sendiri, pelatih yang professional dibidangnya, sarana prasarana yang mendukung semua proses latihan, organisasi yang menaungi proses pembinaan, lingkungan, manajemen dalam proses latihan dengan program latihan yang tepat, pendanaan dan pertandingan untuk melihat peningkatan para atlet. Menurut Sajoto (1995:90) diperlukan faktor-faktor penunjang yang diklasifikasikan menjadi empat aspek, yaitu:

1. Aspek Biologi: kemampuan dasar tubuh, fungsi organ tubuh, postur dan struktur tubuh dan gizi.

2. Aspek Psikologi: Intlegensi/IQ, motivasi, kepribadian, koordinasi kerja otak dan syaraf.

3. Aspek Lingkungan: sosial, sarana dan prasarana, iklim, orang tua, keluarga dan masyarakat.

4. Aspek Penunjang: pelatih berkualitas, program yang tepat, penghargaan dari masyarakat dan pemerintah. 
Proses atlet untuk mewakili di PB Ganesha Kota Batu, menggunakan sistem seleksi pertandingan dan yang menang akan di kirim untuk mewakili Kota Batu dalam pertandingan tingkat provinsi maupun nasional. Menurut Irianto (2002:11) kompetisi merupakan muara dari pembinaan prestasi karena kompetisi dapat digunakan sebagai sarana untuk mengevaluasi hasil latihan serta meningkatkan ke-matangan bertanding olahraganya.

\section{Faktor Eksternal}

Faktor eksternal adalah faktor pendukung yang datangnya dari luar atlet, faktor eksternal dalam penelitian ini meliputi: pelatih, sarana dan prasarana, organisasi, lingkung-an, manajemen, pendanaan dan pertandingan. Selain melakukan latihan yang terprogram dan terencana dengan baik, latihan juga harus didukung dengan fasilitas yang menunjang peningkatan dalam proses latihan dan juga menciptakan atau mengikutkan sertakan dalam kejuaraan agar dapat diuji dan dievaluasi proses latihan selama ini. Semakin banyak atlet megikuti kejuaraan, maka semakin besar peluang untuk mendapatkan atlet yang berprestasi.

Di PB Ganesha Kota Batu sendiri hanya ada 2 orang pelatih bulutangkis yang memiliki lisensi, kedua pelatih tersebut sudah mengikuti penataran pelatih tingkat kabupaten dan provinsi. Pelatih merupakan unsur pendukung yang sangat penting dalam proses pembinaan atlet untuk mengarahkan kemampuan dan keterampilan atlet dalam mencapai prestasi yang optimal. Menurut Sukadiyanto (2011:4) syarat pelatih antara lain memiliki:
(1) Kemampuan dan keterampilan cabang olahraga yang dibina, (2) Pengetahuan dan pengalaman di bidangnya, (3) Dedikasi dan komitmen melatih, (4) Memiliki moral dan sikap kepribadian yang baik.

Pelatih yang ada di PB Ganesha Kota Batu memang banyak tetapi pelatih yang ada semua itu belum memahami ilmu dalam melatih atau belum profesional dan hanya dua orang pelatih yang memiliki sertifikasi lisensi melatih dan sudah memahami ilmu melatih. Kurangnya pengetahuan dan materi dalam melatih adalah salah satu kendala yang akan membuat atletnya cidera bahkan over training, karena pelatih menerapkan metode latihannya tidak mengetahui porsi dan kegunaanya dalam latihan secara baik. Pelatih yang latar belakangnya dari perguruan diharapkan mengikuti pelatihanpelatihan pelatih yang dapat mengembangkan kemampuan dalam melatih, sehingga metode dalam melatih menjadi bervariatif dan tepat sasaran.

Proses pembinaan akan lebih baik dan optimal lagi harus didukung dari faktor lainnya, salah satunya yaitu faktor sarana prasarana yang memadai dan mendukung semua aktivitas latihan. Dengan adanya sarana prasarana yang memadai akan memudahkan para pelatih dalam menerapkan program latihan lebih terstruktur dan terarah. Proses latihan bulutngkis memerlukan sarana prasarana kurang lebihnya meliputi: gedung, lapangan pertandingan (Line), net, tiang net, raket, dan shutllecock. Sarana dan prasarana di PB Ganesha Kota Batu sudah cukup baik, namun masih perlu adanya perawatan dan perbaikan peralatan.

Tabel 7. Sarana dan Prasarana Bulutangkis di PB Ganesha Kota Batu

\begin{tabular}{clcccc}
\hline No & Sarana dan Prasarana & Ada & Tidak ada & Jumlah & Keterangan \\
\hline 1 & Tempat latihan & $\sqrt{ }$ & 1 & Layak \\
2 & (Lapangan Bulutangkis (Line) & $\sqrt{ }$ & 5 & Layak \\
3 & Net/Jaring & $\sqrt{ }$ & 5 & Kurang Layak \\
4 & Tiang Net & $\sqrt{ }$ & 5 & Kurang Layak \\
5 & Kok (Shuttlecock) & $\sqrt{ }$ & - & Kurang Layak
\end{tabular}


Berdasarkan tabel 7 menunjukkan bahwa sarana prasarana Bulutangkis dinyatakan oleh pengurus harian PB Ganesha Kota Batu yaitu: "Sarana dan prasarana di PB Ganesha Kota Batu memang sudah ada dan dibilang sudah memenuhi, tetapi untuk kondisinya perlu di upgrade" Berdasarkan tabel dan wawancara di atas, untuk sarana prasarana sebagai pendukung dalam proses latihan butuh diperbaiki atau diperbaharui lagi. Agar atlet semangat lagi berlatih dan tidak terjadi cidera karena rusak atau belum adanya sarana prasana yang mendukung proses latihan, dan juga pelatih tidak kesulitan dalam melatih. Proses pembinaan olahraga apapun itu pasti membutuhkan namanya organisasi dan manajemen yang baik untuk menaungi para atlet maupun pelatih agar bisa terkelola dengan baik dalam mencapai prestasi optimal, organisasi itu sendiri adalah sekelompok orang yang sudah diberikan posisi masingmasing dan menjalankan tugasnya dengan ketentuan yang sudah dibuat oleh organisasi tersebut untuk mencapai tujuan yang sama serta memanajemen dengan baik. Pada cabang olahraga Bulutangkis di PB Ganesha Kota Batu struktur organsasinya berada di bawah naungan PBSI Kota Batu, dalam pemilihan pengurus PBSI Kota Batu diadakan 5 tahun sekali dan semua anggota PBSI Kota Batu berhak mendelegasikan diri untuk jadi pengurus. Dari sistem pendanaan dan pertandingan bulutangkis PB Ganesha Kota Batu masih perlu di tingkatkan lagi. Sumber dana bulutangkis PB Ganesha Kota Batu berasal dari iuran wali atlet. Iuran dilakukan setiap bulan dengan nominal sebesar Rp. 50.000.

Masalah keuangan sangat menentukan prestasi olahraga mengingat segala kegiatan dalam hal mencapai prestasi secara optimal memerlukan pembiayaan yang tidak sedikit jumlahnya, dengan minimnya pendanaan para atlet akan kurang jam terbang dalam pertandingan dalam hal ini untuk evaluasi sekaligus melihat peningkatan mereka. Peran pengurus bulutangkis PB Ganesha Kota Batu juga terhambat dengan masalah pembiayaan tersebut, dengan event yang tidak pasti pengurus terkendala dalam pembuatan program tahunan dan rapat pengurus hanya diadakan saat ada event pertandingan saja. Jika saja dukungan masyarakat terhadap bulutangkis PB Ganesha Kota Batu banyak yang positif maka proses pembinaan akan berjalan lancar. Sumber daya dari masyarakat perlu dioptimalkan, antara lain, melalui peran serta masyarakat dalam pengadaan dana, pemeliharaan prasarana dan sarana dalam industri olahraga (Ghazali, 2015:1). Untuk dapat mencapai prestasi yang terbaik banyak unsur-unsur didalamnya, Menurut Firmansyah (2013:2) faktor yang menentukan prestasi maksimal ada dua yaitu: (1) Faktor indogen yang meliputi: kesehatan fisik dan mental, penguasaan teknik yang sempurna, kondisi fisik, aspek kejiwaan dan kepribadian yang baik dan memiliki kematangan juara yang mantap. (2) Faktor eksogen yang meliputi: peran seorang pelatih, keuangan, alat, perlengkapan, tempat, organisasi, lingkungan dan prestasi pemerintah. Dari faktor internal dan eksternal yang telah diungkapkan diatas, maka masih banyak hal yang harus diperbaiki seperti proses pemilihan atlet, pelatih, program latihan, organisasi dan menajemen, lingkungan, pendanaan yang belum pasti dan memperjelas event-event pertandingan. Karena kedua faktor tersebut saling berkaitan untuk meningkatkan pembinaan prestasi olahraga khususnya bulutangkis PB Ganesha Kota Batu yang diharapkan.

\section{SIMPULAN}

Berdasarkan hasil penelitian disimpulkan bahwa manajemen pembinaan prestasi cabang olahraga bulutangkis di PB Ganesha Kota Batu memiliki manajemen pembinaan kurang baik.

\section{SARAN}


Ada beberapa saran yang perlu disampaikan sehubungan dengan hasil penelitian ini, antara lain:

1. Agar mengembangkan penelitian lebih dalam lagi tentang survei manajemen pembinaan prestasi bulutangkis di PB Ganesha Kota Batu.

2. Agar melakukan penelitian tentang survei manajemen pembinaan prestasi bulutangkis di PB Ganesha Kota Batu dengan menggunakan metode lain.

\section{REFERENSI}

Aprilia, K.N., Kristiyanto, A. dan Doewes, M. 2018. Analisis Penerapan Prinsip-Prinsip Latihan Terhadap Peningkatan Kondisi Fisik Atlet Bulutangkis PPLOP Jawa Tengah Tahun 2017/2018. Journal Power of Sports, 1(1):55:63.

Azizin, I. 2014. Hubungan Status Gizi dan Aktivitas Fisik dengan Tingkat Kebugaran Jasmani Siswa Sekolah Dasar (Studi pada Siswa Kelas IV dan V MI Al Hikmah Gempolmani). Jurnal Kesehatan Olahraga, 2(2):17-22.

Baker, J., dan Sean, H. 2004. A Review of Primary and Secondary Influences on Sport Expertise. High Ability Studies, 15(2):211-228.

Bompa, T.O., and Haff, G.G. 1994. Periodization Theory and Methodology of Training, Fourth Edition, Colorado: Human Kinetics Phublisher.

Corbin, C., Welk, G. and Corbin, W. and Welk, K. 2019. Concepts of Fitness and Wellness: A Comprehensive Lifestyle Approach Twelfth Edition. USA: McGraw-Hill Education.

Depdiknas. 2010. Pendidikan Jasmani. Jakarta: Balai Pustaka.

Giriwijoyo, H.Y.S.S., dan Sidik, D.Z. 2012. Ilmu Kesehatan Olahraga. Bandung: PT Remaja Rosdakarya.
Harsono. 2015. Kepelatihan Olahraga Teori dan Metodologi. Bandung: Rosda.

Irianto, D.P. 2002. Dasar Kepelatihan. Yogyakarta: Andi.

Kusnaedi, Adisasmita, Y., Ateng, A.K. and Karim, D.A. 2016. Pengaruh Metode Latihan dan Koordinasi Terhadap Keterampilan Smesh Bulutangkis. Jurnal Sains Keolahragaan dan Kesehatan, 1(1):23-28.

Oktian, B.F. 2016. Faktor yang Berhubungan dengan Kebugaran Jasmani. $\left(\mathrm{VO}_{2 \max }\right)$ Atlet Sepak Bola. Jurnal Berkala Epidemiologi, 4(4):237-249.

Putra, G.I. dan Sugiyanto, F.X. 2016. Pengembangan Pembelajaran Teknik Dasar Bulutangkis Berbasis Multimedia pada Atlet Usia 11 dan 12 Tahun. Jurnal Keolahragaan, 4(2):175-185.

https://doi.org/10.21831/jk.v4i2.10 893.

Putri, H. 2015. Faktor yang Berhubungan dengan Kebugaran Mahasiswa Program Studi Kesehatan Masyarakat UIN Syarif Hidayatullah Jakarta. Skripsi. Jakarta: Universitas Islam Negeri Syarif Hidayatullah.

Sajoto. 1995. Peningkatan dan Pembinaan Kekuatan Kondisi Fisik dalam Olahraga. Jakarta: Dahari Prize.

Sarwono. 2008. Hubungan Kebugaran Jasmani Mahasiswa dengan Indeks Massa Tubuh dan Kadar Hemoglobin. Paedogogia. 11(2):124-135.

Simanjuntak, R.H., Engka, J.N.A. and Marunduh, S.R. 2016. Pengaruh Latihan Fisik Akut Terhadap Saturasi Oksigen Pada Pemain Basket Mahasiswa Fakultas Kedokteran Unsrat. Jurnal $e$ Biomedik, 4(1). pp. 20-24.

Sugiharto. 2014. Fisiologi Olahraga: Teori dan Aplikasi Pembinaan Olahraga. Malang: UM Press. 
Sukadiyanto. 2002. Metodologi Pembentukan Kondisi Fisik Petenis. Yogyakarta: FIK UNY.

Sule, E.T. dan Saefullah, K. 2005. Pengantar Manajemen Edisi
Pertama. Jakarta: Kencana Pranada Media Grup.

Tohidin, D. 2007. Adaptasi Fisiologi dalam Olahraga. Malang: Wineka Me 
